J. Perinat. Med. $11(1983) 286$

\section{Maternal half-sitting position in the second stage of labor}

\author{
M. Marttila, P. Kajanoja, O. Ylikorkala
}

First and Second Departments of Obstetrics and Gynecology, University of Helsinki, Finland
With the progress of civilization the maternal position during labor has changed from the erect to the supine one. Nowadays the wisdom of this change is commonly questioned $[10,12]$. Indeed, there is some evidence suggesting the benefits of maternal ambulation during the first stage of labor $[2,4,6,11,13]$. The erect position could be even more useful during the second stage of labor, when the gravity might enhance the delivering force. Furthermore, the pelvic measures may be larger in the half-sitting than supine position $[3,5]$. Because, however, no controlled data exist on the effect of maternal position during the second stage of labor we compared here the labor progress and other variables of the mothers delivering in halfsitting and supine position.

\section{Subjects and methods}

One hundred women with uncomplicated pregnancies went into labor spontaneously $(n=97)$ or after the i.v. infusion of oxytocin for 2-3 hours $(n=3)$ between the 38 th and 42 nd weeks of gestation. During the first stage of labor the women stayed in supine position except for 8 mothers who stood up for a brief walk when the cervix was dilated $4-6 \mathrm{~cm}$. When the cervix was fully dilated, the women were randomly allocated to two groups, the ones who stayed in supine position and those who were lifted to half-sitting position $\left(50^{\circ}\right)$ in a delivery chair which was

\section{Curriculum vitae}

MARION MARTTILA was born 1950 in Helsinki. Licenciate of Medicine from University of Helsinki 1975. Specialist in Obstetrics and Gynecology from Department I of Obstetrics and Gynecology of University of Helsinki 1982. Present position: Private practitioner.

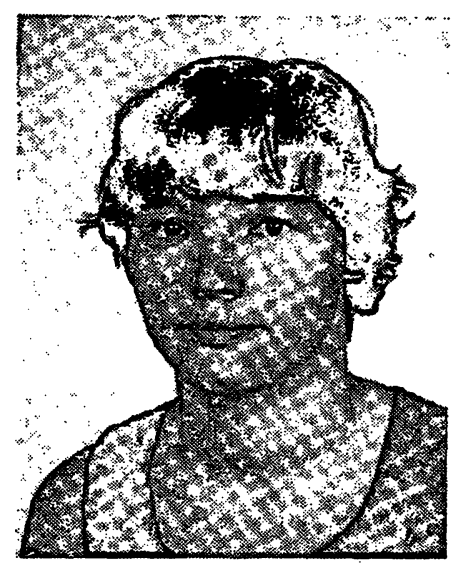

constructed from their delivery beds. Lateral episiotomy was done routinely in all women except for two multiparas. The groups were comparable in regard to the maternal age, parity, gestational age, use of analgetics during the opening phase, length of the first stage of labor and infant birth weight (Tab. I). No analgetics were given during the second stage of labor.

The variables recorded were: The length of the second stage (the time from the full dilatation of the cervix to the birth of the infant), the active second stage (the time spent in active pushing of the infant), the occurrence of tears and instrumental deliveries, early and late decelerations [1] as well as bradycardia ( $<90$ beats/min) in fetal cardiotocography and APGAR score.

Furthermore, the women were asked for the severity and localization of the pains as well as for other subjective symptoms on special question- 
Tab. I. Clinical characteristics (mean \pm SD) of the study populations delivering half-sitting or supine position. No differences are seen.

\begin{tabular}{lcccr}
\hline & Half-sitting & \multicolumn{2}{l}{ Supine } \\
\hline & 50 & & 50 & \\
\hline $\begin{array}{l}\text { Number of women } \\
\text { Agc (years) }\end{array}$ & $27.3 \pm$ & 4.2 & $28.8 \pm$ & 4.1 \\
$\begin{array}{l}\text { Parity (number) } \\
\quad \text { - primiparous }\end{array}$ & 30 & & 30 & \\
$\quad$ - multiparous & 20 & & 20 & \\
$\begin{array}{l}\text { Gestational age } \\
\begin{array}{l}\text { (wecks) } \\
\text { Length of the first }\end{array}\end{array}$ & $40.3 \pm$ & 1.0 & $40.4 \pm$ & 0.9 \\
$\begin{array}{l}\text { stago (hours) } \\
\quad \text { - primiparous }\end{array}$ & $10.2 \pm$ & 4.8 & $10.2 \pm$ & 4.8 \\
$\quad$ - multiparous & $7.4 \pm$ & 3.1 & $7.1 \pm$ & 4.2 \\
$\begin{array}{l}\text { Fetal weight (grams) } \\
\text { Husband present } \\
\text { (number) }\end{array}$ & $3652 \pm 417$ & $3632 \pm 425$ \\
\hline
\end{tabular}

naires which were filled in two hours after the delivery.

The results were analysed by STUDENT's t-test and CHI-analysis.

\section{Results}

All women delivered vaginally. Vacuum extraction due to maternal or uterine exhaustion was needed six times $(12 \%)$ in mothers delivering in supine and twice $(4 \%)$ in those with a half-sitting position $(p>0.05)$. The length of the whole or active second stage did not differ between the groups (Tab. Il). Although early decelerations in fetal cardiotocography in mothers delivering halfsitting position $(n=22)$ were more common $(p<0.05)$ than those in mothers staying in supine $(n=14)$, the cardiotocographic changes which are

Tab. II. The duration of the second stage of labor (mean $\pm \mathrm{SD}$ ) in mothers delivering in half-sitting or supine positon. No differences are seen.

\begin{tabular}{lll}
\hline & Half-sitting & Supine \\
\hline $\begin{array}{l}\text { The total second stage } \\
\text { of labor (min) }\end{array}$ & & \\
$\quad$ - primiparous & $42.8 \pm 33.9$ & $41.4 \pm 24.0$ \\
$\quad$ - multiparous & $20.1 \pm 25.0$ & $19.9 \pm 37.2$ \\
$\begin{array}{l}\text { The active second stage } \\
\text { of labor (min) }\end{array}$ & & \\
- primiparous & $21.8 \pm 14.9$ & $25.0 \pm 14.8$ \\
- multiparous & $17.2 \pm 22.1$ & $10.6 \pm 16.2$ \\
\hline
\end{tabular}

Tab. III. Changes in fetal cardiotocography during the second stage of labor and APGAR scores of the infants born to the mothers giving birth in half-sitting and supinc position.

\begin{tabular}{|c|c|c|c|c|}
\hline & \multicolumn{2}{|c|}{ Half-sitting } & \multicolumn{2}{|l|}{ Supine } \\
\hline $\begin{array}{l}\text { Cardiotocographic } \\
\text { changes } \\
\text { (number of women) } \\
\text { - early decelerations } \\
\text { - late decelerations } \\
\text { - bradycardia } \\
\text { (<90 beats/min) } \\
\text { - late decelerations } \\
\text { and bradycardia }\end{array}$ & $\begin{array}{c}29 \\
22^{8} \\
1 \\
6 \\
0\end{array}$ & & $\begin{array}{c}25 \\
14^{b} \\
4 \\
6 \\
1\end{array}$ & \\
\hline $\begin{array}{l}\text { APGAR scores } \\
\text { (Number of infants) }\end{array}$ & $1 \mathrm{~min}$ & $5 \mathrm{~min}$ & $1 \mathrm{~min}$ & $5 \mathrm{~min}$ \\
\hline $\begin{array}{l}9-10 \\
8 \\
7 \text { or less }\end{array}$ & $\begin{array}{r}43 \\
7 \\
0\end{array}$ & $\begin{array}{r}50 \\
0 \\
0\end{array}$ & $\begin{array}{r}43 \\
3 \\
4\end{array}$ & $\begin{array}{r}49 \\
1 \\
0\end{array}$ \\
\hline
\end{tabular}

a vs $b ; p<0.05$

more indicative of fetal asphyxia (late decelerations, bradycardia), tended to be more common in mothers delivering in supine position (Tab. III). Likewise the APGAR scores were slightly better in half-sitting than in supine group (Tab. III).

Vaginal tcar was detected in one mother in both groups. The episiotomics bled equally in both groups.

Subjectively, intolerable pain was reported by four women in a supine but by none in half-sitting position. The maximum pain was similarly localized in both groups mostly towards the rectum or in the lower abdomen. Nine mothers with supine and five with half-sitting position regarded the delivery as an unpleasant experience. The majority of the women delivering now in supine $(86 \%)$ or half sitting $(96 \%)$ position wished to deliver her next child in half-sitting position.

\section{Discussion}

The laymen have focused recently much interest in the maternal position during the second stage of labor. This was also evident from the present work, because $86 \%$ of the women delivering now in supine position wished to deliver her next child in sitting position. The obstetricians and midwives 
have found it difficult to participate in this discussion because no controlled data have existed in favor or disfavor of the maternal sitting position during the second stage of labor.

We compared here the half-sitting and supine position of the mothers during the second stage of labor. From the maternal point of view, no objective differences were seen, although subjectively the half-sitting position was regarded more pleasant. The objective recording of fetal condition can be more difficult during the second than first stage of labor. Early decelerations were seen more frequently in our subjects delivering in half-sitting than supine position. This may be a result of enhanced delivering force, as also suggested by fewer vacuum extractions needed in half-sitting group. Early decelerations should not, however, be regarded as a sign of fetal asphyxia $[7,8]$, and indeed, the cardiotocographic changes which are more reliable during the second stage of labor, were somewhat less frequent in half-sitting than supine group. Furthermore APGAR scores tended to be better in the group delivering in halfsitting than supine position in our study. This may come from the fact that a maternal supine position may lead to the development of the vena compression syndrome which in turn can result in a fall of fetal oxygen pressure [9]. Perhaps the variables studied might have differed more if a larger number of mothers had been studied and/or a more erect position employed.

Subjectively, the mothers preferred the half-sitting position. This may suggest some advantages of a maternal erect position which are objectively unmeasurable. Another explanation could be that a delivery in a "fashion like" way was more positively experienced.

Summarizing our results we conclude that although a maternal half-sitting position was not superior to a supine one, it was no worse either. Therefore, a delivering woman should be allowed to adopt a half-sitting position if she wants to do so.

\section{Summary}

The maternal half-sitting and supine position during the second stage of fullterm labor was compared in 100 women who, after identical opening phases in supine position, randomly delivered in half-sitting $\left(50^{\circ}, \mathrm{n}=50\right)$ or supine position $(n=50)$.

The whole duration of the second stage of labor or the time spent in active pushing did not differ between the groups. Vacuum extraction was needed twice $(4 \%)$ in the group delivering in half-sitting and six times $(12 \%)$ in the group delivering in supine position. Vaginal tear occurred in one mother in both groups. Early decelerations in fetal

cardiotocography were seen 22 times in half-sitting and 14 times in supine group $(p<0.05)$. However, late decelerations were seen in only one mother with half-sitting, as compared to five mothers with supine position. Four infants of mothers giving birth in supine position had 1 minute APGAR scores 7 or less, whereas all infants of mothers delivering in half-sitting position had APGAR scores higher than 7 . Subjectively the mothers liked more the half-sitting position. We conclude that a women can deliver in half-sitting position without maternal or fetal risks.

Keywords: Deceleration, delivery chair, duration, half-sitting position, labor, second stage.

\section{Zusammenfassung}

Halbsitzende Position der Gebärenden in der Austreibungsphase

Bei 100 Frauen am Termin haben wir nach vergleichbarer Eröffnungsphase die halbsitzende Position und die Rückenlage in der Austreibungsphase miteinander verglichen. 50 zufällig ausgewählte Frauen wurden in halbsitzender Position $\left(50^{\circ}\right)$ entbunden, die anderen 5.0 in Rückenlage.

Bezüglich der Dauer der aktiven Austreibungsperiode gab es zwischen den beiden Gruppen keinen Unterschied. Eine Vakuumextraktion war in 2 Fällen (4\%) bei den Frauen, die halbsitzend entbunden wurden, nötig, in der anderen Gruppe in 6 Fällen (12\%). In beiden Gruppen kam es jeweils einmal zu einem Dammriß. Im CTG zeigten sich in 22 Fällen bei der halbsitzenden Position Frühdezelerationen, in Rückenlage bei 14 Fällen ( $p<0,05)$. Spätdezelerationen wurden in nur 1 Fall bei der halbsitzenden Position, jedoch in 5 Fällen bei der Rückenlage beobachtet. $4 \mathrm{Kinder}$, die aus der Rückenlage geboren wurden, hatten einen APGAR-Score 1 Minute post partum von $\leqslant 7$; in der anderen Gruppe war der APGAR-Score in allen Fällen höher als 7. Subjektiv bevorzugten die Frauen die Geburt aus halbsitzender Position. Unsere Schlußfolgerung lautet, daß Frauen ohne eigene Gefährdung oder Gefährdung des Kindes in der halbsitzenden Position gebären können.

Schlüsselwörter: Austreibungsphase, Dezelerationen, Gebärstuhl, Geburt, Geburtsdauer, halbsitzende Position. 


\section{Résumé}

\section{Position maternelle demi-assise pendant l'expulsion}

On a comparé la position demi-assise et en décubitus dorsal pendant l'expulsion chez 100 femmes à terme qui, après une phase de dilatation identique en décubitus dorsal, ont été randomisées en position demi-assise (à $50^{\circ}, n=50$ ) ou en décubitus dorsal $(n=50)$.

La durée globale de la phase d'expulsion et la durée des efforts expulsifs ne diffèrent pas dans les deux groupes.

Une extraction par ventouse a été nécessaire deux fois (4\%) dans le groupe en position demi-assise et six fois (12\%) dans le groupe en décubitus dorsal. Il y a une déchirure vaginale chez une mère dans chaque groupe. Des décélérations précoces sur le cardiotocographe ont été observées 22 fois dans le groupe en position demi-assise et 14 fois dans le groupe en décubitus dorsal $(p<0,05)$. Toutefois, des décélérations tardives n'ont été observées que chez une mère dans le groupe en position demi-assise, en comparaison de 5 mères dans le groupe en décubitus: Quatre enfants de mères ayant accouché en décubitus ont eu un APGAR égal ou inférieur à 7, alors que tous les enfants des mères ayant accouché en position demi-assise ont eu un APGAR supérieur à 7 .

De façon subjective, les mères ont préféré la position demi-assise.

Nous concluons qu'une femme peut accoucher en position demi-assise, sans risque maternel fœtal.

Mots-clés: Chaised d'accouchement, décélération, durée, expulsion, travail en position demi-assise.

\section{Bibliography}

[1] BOLOGNESE, R. J., R. H. SCHWARZ: Management of the High Risk Fetus and Neonate. Perinatal Medicine 70. Thieme, Stuttgart 1977.

[2] CALDEYRO-BARCIA, R.: Influence of maternal position in labor. IX World Congress of Gynecology and Obstetrics. Seminare s-6, Tokyo (1979)

[3] EHRSTRÖM, C: Föda barn i sittande ställning. Läkartidningen 78 (1981) 4016

[4] FLYNN, A. M., J. KELLY, G. HOLliNS, P. F. LYNCH: Ambulation in labour. Brit. Med. J. 2 (1978) 591

[5] HAUKELAND, I.: An alternative delivery position: New delivery chair developed and tested at Kongsberg Hospital. Amer. J. Obstet. Gynec. 141 (1981) 115

[6] HAUKKAMAA, M., M. PURHONEN, K. TERAMO: The monitoring of labor by telemetry. J. Perinat. Med. 10 (1982) 17

[7] KATZ, M., N. SHANI, I. MEIZNER, U. INSLER: Is end-stage deceleration of the fetal heart omnious? Brit. J. Obstet. Gynaecol. 89 (1981) 186

[8] KREBS, H. B., R. E. PETERS, L. J. DUNN : Intrapartum fetal heart rate monitoring. V Fetal heart rate patterns in the second stage of labor. Amer. J. Obstet. Gynec. 140 (1981) 435

[9] KURZ, C. S., H. SCHNEIDER, R. HUCH A. HUCH: The influence of the maternal position on the fetal transcutaneous oxygen pressure. J. Perinat. Med. 10 (1982) 74
[10] MCMANUS, T. J., A. A. CALDER: Upright posture and the efficiency of labour. Lancet Jan. 14 (1978) 72

[11] MENDEZ-BAUER, I. ARROYO, U. FREESE, C. GARCIARAMOS, P. HUNDSDORFER, F.IZQUIERDO, M. LAVILLA, J. MANAS, J. MARTINEZ, A. MENENDEZ, L. REINA, J. ROBERTS, A. RUIZ-CANCECO, A. STEINER, J. ZAMARRIEGO-CRESPO: The dynamics of labor in different positions. VIIth European Congress of Perinatal Medicine, Barcelona (1980)

[12] MITRE, I. N.: The Influence of Maternal Position on Duration of the Active Phase of Labor. Int. J. Gynaec. Obstet. 12 (1974) 181

[13] SCHNEIDER-AFFELLD, F., K. MARTIN: Delivery from a sitting position. J.Perinat. Med. 10 (1982) 70

Received February 25, 1983. Revised March 18, 1983. Accepted June 4, 1983.

Dr. Olavi Ylikorkala

First Department of Obstetrics and Gynecology University of Helsinki

Haartmaninkatu 2

SF-00290 Helsinki 29, Finland 